DOI https://doi.org/10.18551/rjoas.2017-09.20

\title{
COST, TIME, AND QUALITY ANALYSIS OF PRECAST CONCRETE CONSTRUCTION AND IN SITU CONCRETE AT MACRO CHANNEL IN CONTROL OF RUN-OFF: A CASE STUDY OF REGIONAL HARUN NAFSI STREET IN SAMARINDA
}

\author{
Syahrizal Muhammad*, Hidayat Sutanto, Santosa Agus \\ Study Program of Civil Engineering, Concentration of Construction Management, \\ National Institute of Technology, Malang, Indonesia \\ *E-mail: myrizaldii@gmail.com
}

\begin{abstract}
The aims of this study are to calculate the construction cost which is required in the implementation of method of precast and cast concrete construction in its place; calculate the required time in the construction method of precast and cast concrete in its place; analyze the quality of construction of precast and cast concrete method in its place and resulting in the K-250 of quality value. The selection of construction method is important in a construction project work because the right implementation method can provide maximum results, especially when it is viewed in terms of construction cost, time and quality. The construction of comparative cost selection method for In Situ and precast concrete materials uses Office of Highways Analysis 2010 Revision 3, implementation time uses S curve and construction quality uses questionnaire. Based on the result of construction cost plan of In Situ concrete construction of Rp. $109,790,340,000.00$, the budget plan for the construction of precast concrete is Rp. 73.460.740.000.00. The calculation of the need for working time is In Situ concrete construction method needs 2 years 1 month and precast concrete construction method needs 1 year 8 months. The quality of precast concrete construction shows that the precast concrete surface is more neatly, better and more subtle than In Situ concrete. Field dimensions are safer and the quality of precast concrete is guaranteed as the sale of the product which is coupled with the concrete specified from the In Situ.
\end{abstract}

\section{KEY WORDS}

Concrete, cost, time, quality.

Samarinda as the provincial capital, the rapid urbanization and migration from other areas has spurred the residential development that tends to deviate from the concept of sustainable development. The numbers of low areas (swamps, lakes) which initially serves as water reservoir and the riverbanks were turned into residential areas, coupled with the habits of the people who throw garbage into the river further worsen this condition. The topography of Samarinda in which it has many areas below the surface of the elevation of the river makes the reason why flood frequently occurs in Samarinda, but actually not only a topographical issue that needs to know that makes the flood in Samarinda.

Selection of a method is very important in the implementation of a construction project because the right method of implementation can provide maximum results, especially when it is viewed from Construction Costs, Implementation Time, and Construction Quality, (Kulkarni et al, 2008). With the rapid technological advancement in the world of construction, it allows project managers to choose one of the specific construction methods from some alternative existing construction methods, (Pampanin et al, 2001). One of the efforts undertaken by the project manager is to replace the cast concrete in a more modern place that is by the application of precast concrete, (Mirmiran et al, 2001). The use of precast concrete is expected to respond to industrialization challenges that require effective, efficient, quality and economic results.

In general, the use of precast concrete is considered more economical compared to in situ concrete due to the effect of weather with high rainfall and it can also reduce the cost of using formwork and reduce the duration of the project implementation so that the overhead resulted becomes smaller, (Kurama, 2000). In addition, working on the ground surface is 
much easier and safer to do, such as molds, casting, surface hearth, maintenance, and repeated use of formwork, (Ervianto, 2006).

From the above explanation, the researcher attempts to give alternative of choosing the implementation method by researching from the aspect of Construction Cost, Implementation Time, and Construction Quality and to know which one is the most economical betwee the channel installation of pre-cast concrete and In situ concrete.

The purposes of this study are to (i) calculate the cost of construction required in the implementation of precast concrete construction and In situ concrete methods; (ii) calculate the required execution time in the construction method of precast concrete and In situ concrete; (iii) how does the quality of construction in the implementation of precast concrete and In Situ concrete methods result in K-250 quality values.

\section{LITERATURE REVIEW}

Drainage. Drainage is a means of removing undesirable excess water in an area as well as a way to overcome the effects caused by the excess water. The purpose and objective of drainage is to dispose water over excessive soil surface, reduce and maintain water surface rather than puddle, so the negative effect with the existence of puddles and overflow of water can be avoided. (Suhardjono, 1984)

Understanding Precast Concrete. Precast concrete is a construction technology of concrete structures with pre-assembled components, sometimes the components are arranged and pre-assembled, and then it is installed at the installation site. Thus, this precast system will be different from monolith construction, especially in planning aspect which depends on or determined by execution method of fabrication, unification, and installation, and also determined by technical behavior of precast system in the way of connection between component join (Abduh, 2007). Some principles are believed to benefit more from precast concrete technology such as: time, cost, quality, predictability, reliability, productivity, health, safety, environment, coordination, innovation, reusability, and relocatability (Gibb, 1999; Abduh, 2007).

History of Precast System Development. Precast concrete construction has been growing rapidly in the world, including in Indonesia in the last decade, because this system has more advantages than conventional systems. Especially in the field of medium skyscraping buildings, such as Simple Flats, Precast System has been proven to support the development of high-quality, fast and economical housing complexes. The synergy among government, universities, researchers, inventors, research institutes, and industries in this field has resulted in dozens of newly-created and actively-adopted nation-building systems of the nation's generation, (Abduh, 2007).

Development of Precast System in the World. Modern precast system was developed early in European countries. The precast structures were first used as precrete concrete blocks for the Casino in Biarritz, built by Coignet contractor Paris 1891. The reinforced concrete foundation was introduced by a German company, Wayss \& Freytag in Hamburg and began to be used in 1906. In 1912 several skyscraping buildings used Precast system of components, such as walls, columns and floors introduced by John.E.Conzelmann. The structure of prefabricated reinforced concrete components was also introduced in Germany by Philip Holzmann AG, Dyckerhoff \& Widmann G Wayss \& Freytag KG, Prteussag, Loser etc.

Development of Precast System in the World. Indonesia has been familiar with precast system components such as piles, bridge beams, columns, and floor plates since the 1970s. The precast system is growing with the marking of innovations, such as Column Slab System (1996), L-Shape Wall System (1996), All Load Bearing Wall System (1997), Beam Column Slab System (1998), Jasubakim System (1999), Bresphaka (1999), and the T-Cap system (2000). The fundamental issues in the development of precast systems in Indonesia today are:

- The system is relatively new;

- Less socialized types, products and the ability of precast systems that already exist; 
- The absence of official guidance on procedures of analysis, planning and specific level of control for precast system that can be used as guidance for the perpetrators of construction.

Ditch Precast Concrete. U-Ditch is a channel of reinforced concrete with a U-shape cross section and it can also be closed. Commonly it is used as drainage or irrigation channels. The height of these open channels may vary following the needs in the field or the desired channel elevation. The type of joint is a joint plate (embedded plate and joint but male or female joint) where in the meeting part, its connection is sufficient to provide mortar as a grout cover.

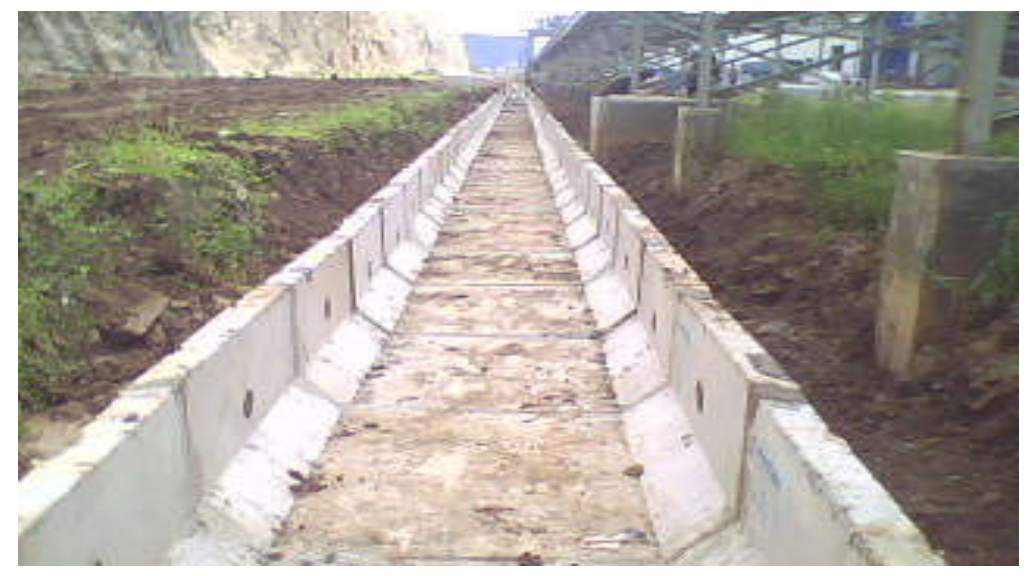

Figure 1 - U-Ditch

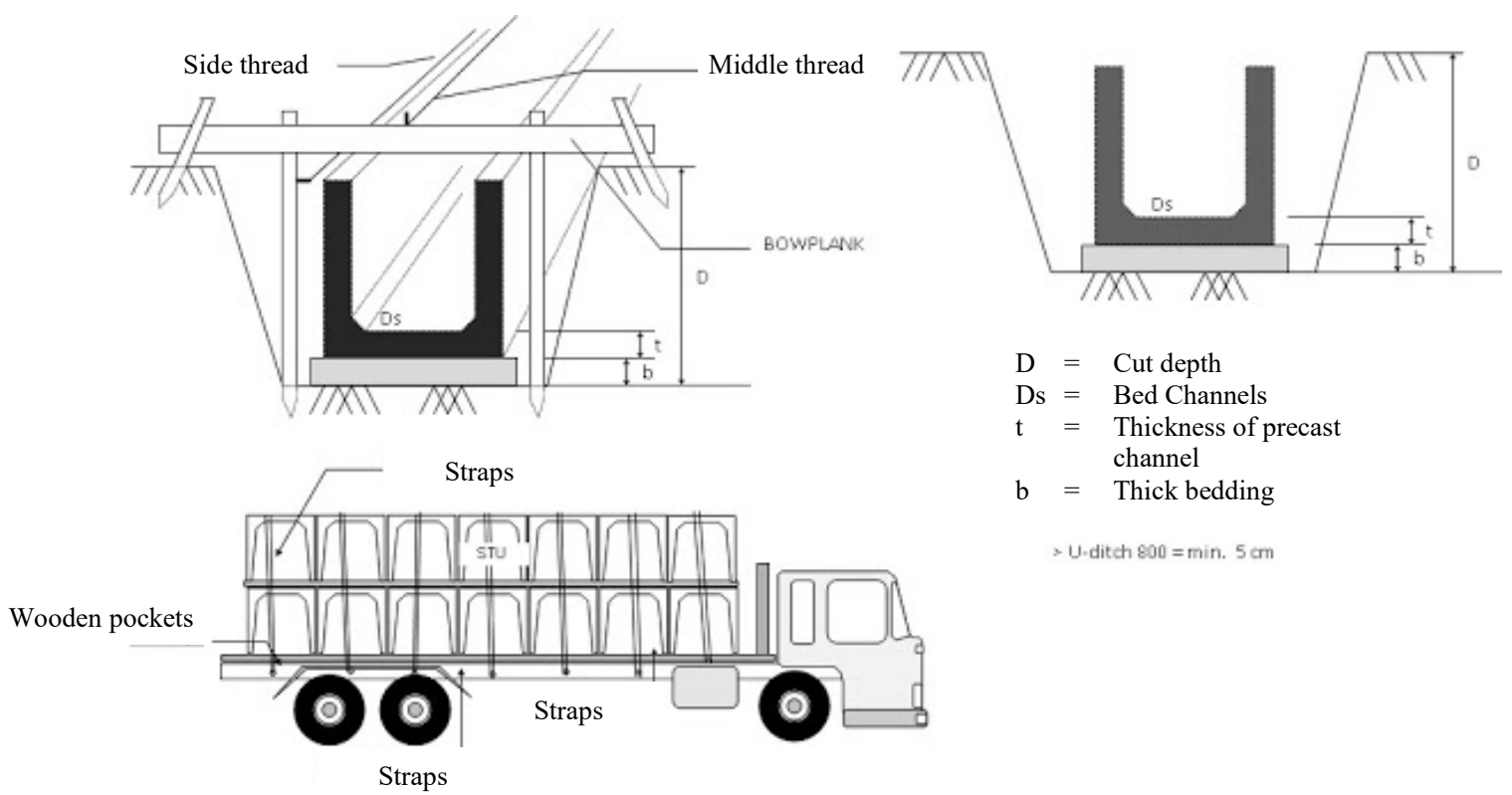

Figure 2 - Transport of U-DITCH

Budget Plan (BP). Activity estimation is one of the main processes in a construction project to answer, "How much money should be reserved for a building?". In general, the cost required in a construction project is large, (Jarkas, 2005). The inaccuracy that occurs in its supply will have a negative effect on the parties involved (Ervianto, 2005). The cost budget of a building or project is a calculation of the amount of costs required for materials and labor wages based on analysis as well as other costs associated with the implementation of work. Ibrahim (2003) states that the cost or the budget itself is the sum of each result of the multiplication of the volume with the unit price of the work. It is concluded that the budget plan of the work is shown in the formula: 


$$
B P=\Sigma(V O L U M E X \text { WORK UNIT PRICE) }
$$

The unit price of materials and labor wages in each region vary. Thus, in determining the calculation and preparation of the budget cost of a work, it should be guided by the price of material units and wages of labor in the market and location of work.

Job Plan Description (Network Planning). The S curve is one of the most commonly used cost control planning methods utilized in a project. The $S$ curve represents the percentage of the cumulative cost plot diagram plotted on a coordinate axis in which the abscissa axis $(X)$ denotes the time of projection and axis $Y$ represents the percent value of the cumulative cost during the life of the project. In the diagram of the $S$ curve, the expenditures spent time units, cumulative cost expenses per unit time, and work progress based on the volume generated in the field can be seen. The way to make the actual S curve is the actual $S$ curve in the plot of the plan curve $S$ in the same way as making the $S$ plan curve. The difference is in the calculation of the labor cost per unit of time which is calculated based on the physical volume generated multiplied by the unit price of the work (the volume generated is circulated from the work of the owner performed by the owner or the representative and the result of the legitimate and accountable re-registration)

The Barchat is a chart containing a chart listing the activities that will be performed, arranged in a downward march where each activity has the required execution time (duration) shown in the form of a timeline (usually a line so that it is like a beam). The length of each line / block indicates the length of time required for each activity as well as the time to start and to end the activity (Soeharto, 1999). While the unit of time can be a day, week, month or a certain time interval. To calculate the percentage of weight of each type of activity, both the cost of each activity and the total cost of the work should be know. The percentage weight calculation for each type of activity is as follows:

$$
\text { Activity weight }=\frac{\text { total activity cost }}{\text { total cost }} \times 100 \%
$$

\section{METHODS OF RESEARCH}

Analysis of Budget Plan. After calculating drainage channel capacity in 2015 condition with 10-year repeat period, then cost budget by using Office of Highways analysis is calculated. Calculation of material prices uses HSBJ City Government 2016. The calculation of budget cost is done by two kinds of calculation with the aim of finding the most economical cost comparison which are: a) calculation of budget plan cost of In Situ concrete method/conventional system, b) calculation of cost budget plan of precast / precast concrete method.

Analyzing Calculation of Time Requirement of workmanship. Using the curve $S$ depiction can be assumed that the cost of each item is evenly distributed over its duration, (Marriott et al, 2009). This condition is not always true because it is possible that a work item with a large material purchase cost (absorbing more than $50 \%$ of the total price of the job) will be absorbed at the beginning of the job and the remaining duration is done for the installation fee.

Quality Analysis. It is done by using a questionnaire with contingency questions. It means that the question form that still goes on. This type of question is possible, but it must be based on the possibility of a certain relationship between one theme with another theme. In addition, answers from respondents to this follow-up question will greatly help to deepen the insights of researchers. The type of research scale used is the Semantic Differential Scale, the semantic difference scale (the science of word meaning) which contains a series of bipolar characteristics (two poles). The semantic differential scheme has three basic dimensions of someone's attitude toward objects: the potential or strength of the object; evaluation or disadvantage or disadvantage of an object; activity or movement level of an object. 


\section{RESULTS AND DISCUSSION}

In the calculation of RAB is obtained results as follows:

- Cost budget plan for In Situ concrete construction method is Rp. 109,790,340,000.00.

- Cost budget plan for precast concrete construction method is Rp. 73.460.740.000,00.

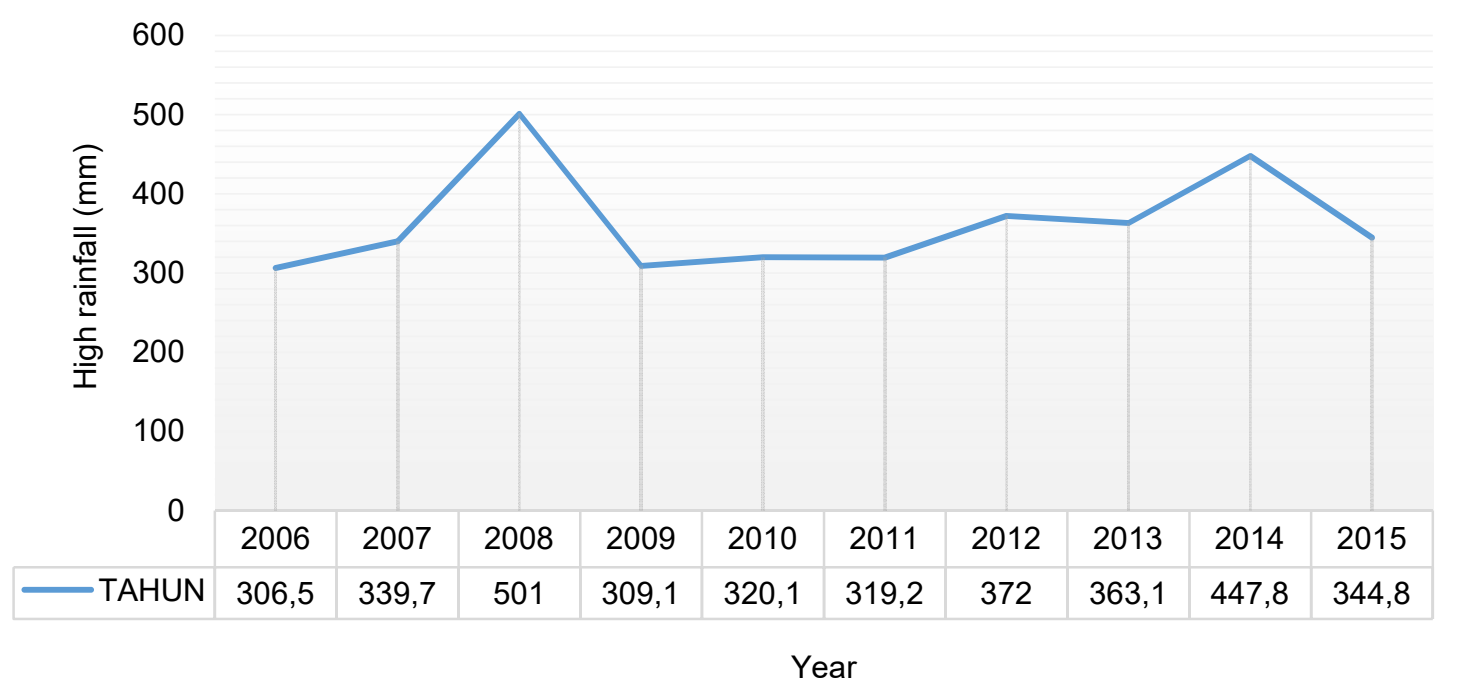

Figure 3 - Monthly Average Rainfall Characteristics of Sta. Temindung

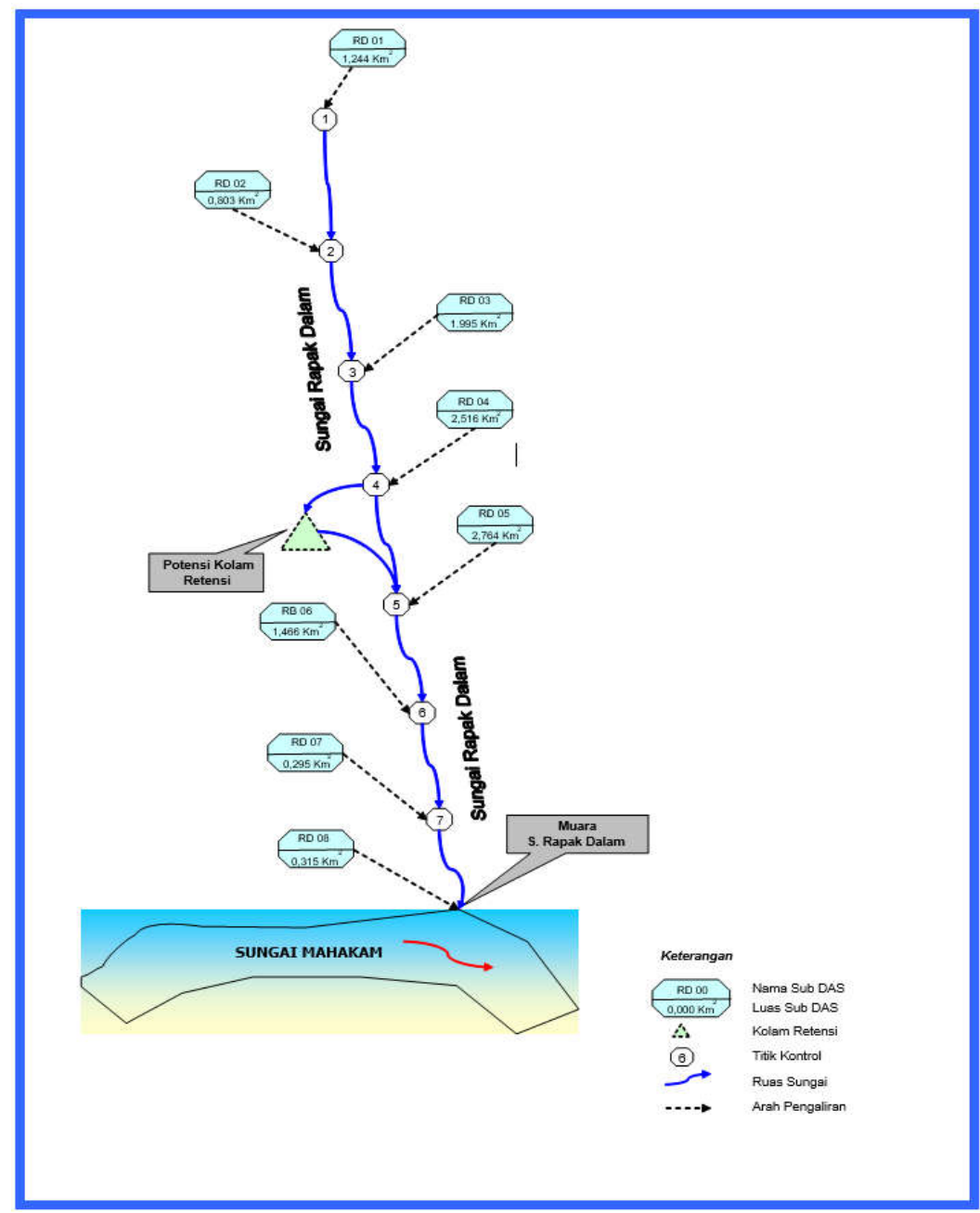

Figure 4 - Rapak Dalam DAS Scheme 
Table 1 - List Quantity in Situ Concrete

\begin{tabular}{|c|c|c|c|c|c|}
\hline $\begin{array}{c}\text { No. } \\
\text { Payment }\end{array}$ & Description & Unit & $\begin{array}{l}\text { Estimated } \\
\text { Quantity }\end{array}$ & $\begin{array}{c}\text { Price } \\
\text { Unit } \\
\text { (Rupiah) }\end{array}$ & $\begin{array}{c}\text { Amount } \\
\text { Prices } \\
\text { (Rupiah) }\end{array}$ \\
\hline$a$ & $\mathrm{~b}$ & C & $\mathrm{d}$ & $\mathrm{e}$ & $f=(D X E)$ \\
\hline \multicolumn{6}{|c|}{ DIVISION 1. GENERAL } \\
\hline 1.2 & Mobilization & LS & 1.00 & $41,500,000.00$ & $41,500,000.00$ \\
\hline \multicolumn{5}{|c|}{ Work Price Total of DIVISION 1 (in Recapitulation of Estimated Price of Work) } & $41,500,000.00$ \\
\hline \multicolumn{6}{|c|}{ DIVISION 2. DRAINAGE } \\
\hline 2.1 & $\begin{array}{c}\text { Digging for Drainage \& Water } \\
\text { Channel }\end{array}$ & $M^{3}$ & 24401.79 & 54027.17 & $1,318,359,496.38$ \\
\hline \multicolumn{5}{|c|}{ Work Price Total of DIVISION 2 (in Recapitulation of Estimated Price of Work) } & $1,318,359,496.38$ \\
\hline \multicolumn{6}{|c|}{ DIVISION 3. GROUND WORK } \\
\hline 3.2. (1) & Landfill & $\mathrm{M}^{3}$ & 964.46 & $149,832.81$ & $144,507,750.25$ \\
\hline \multicolumn{5}{|c|}{ Work Price Total of DIVISION 3 (in Recapitulation of Estimated Price of Work) } & $144,507,750.25$ \\
\hline \multicolumn{6}{|c|}{ DIVISION 7. STRUCTURE } \\
\hline $7.1(5)$ & K-250 Concrete & $\mathrm{M}^{3}$ & 48915.55 & 1432901.85 & $70,091,182,209.30$ \\
\hline $7.1(8)$ & K-125 Concrete & $\mathrm{M}^{3}$ & 2435.15 & $1,075,151.78$ & $2,618,155,865.61$ \\
\hline 7.3 & Reinforcing Steel & $\mathrm{Kg}$ & $1,004,474.93$ & 21095.04 & $21,189,433,752.24$ \\
\hline $7.6(1)$ & $\begin{array}{l}\text { Erection of Ironwood } 10 \times 10-200 \\
\mathrm{~cm}\end{array}$ & $M^{1}$ & 73472.00 & 58600.35 & $4,305,484,915.20$ \\
\hline $7: 11(1)$ & Pipework 1 & "M & 6888.00 & 14630.74 & $100,776,546.30$ \\
\hline
\end{tabular}

Table 2 - The Quantity of Precast Concrete

\begin{tabular}{|c|c|c|c|c|c|}
\hline $\begin{array}{l}\text { No. } \\
\text { Pay- } \\
\text { price }\end{array}$ & Description & Unit & $\begin{array}{l}\text { Estimated } \\
\text { Quantity }\end{array}$ & $\begin{array}{c}\text { Price } \\
\text { Unit } \\
\text { (Rupiah) }\end{array}$ & $\begin{array}{c}\text { Total } \\
\text { Price } \\
\text { (Rupiah) }\end{array}$ \\
\hline$a$ & $\mathrm{~b}$ & $\mathrm{C}$ & $\mathrm{d}$ & $\mathrm{e}$ & $f=(D X E)$ \\
\hline \multicolumn{6}{|c|}{ DIVISION 1. GENERAL } \\
\hline 1.2 & Mobilization & LS & 1.00 & $41,250,000.00$ & $41,250,000.00$ \\
\hline \multicolumn{6}{|c|}{ DIVISION 2. DRAINAGE } \\
\hline 2.1 & $\begin{array}{l}\text { Digging for Drainage \& Water } \\
\text { Channel }\end{array}$ & $M^{3}$ & 26565.39 & 54027.17 & $1,435,252,679.16$ \\
\hline $2.3 a$ & U-ditch $1 \times 1.5$ & $M^{\prime}$ & 225.00 & 42905.56 & 9659390.17 \\
\hline 2.3.B & U-ditch $1.5 \times 2$ & $M^{\prime}$ & 50.00 & $3,783,763.96$ & $851,346,890.17$ \\
\hline 2.3.c & U-ditch $3 \times 2$ & $\mathrm{M}^{1}$ & 500.00 & $5,913,515.83$ & $295,675,791.69$ \\
\hline $2.3 . d$ & U-ditch $4 \times 2$ & $M^{\top}$ & 2022.00 & $7,543,267.71$ & $3,771,633,855.59$ \\
\hline $2.3 . e$ & U-ditch $6 \times 2.5$ & $\mathrm{M}^{\top}$ & 370.00 & $13,802,730.98$ & $5,107,025,442.43$ \\
\hline $2.3 . f$ & U-ditch $7 \times 2.5$ & $M^{1}$ & 1425.00 & $18,807,479.01$ & $26,800,720,764.43$ \\
\hline \multicolumn{5}{|c|}{ Work Price Total of DIVISION 2 in Recapitulation of Estimated Price of Work)) } & $59,842,501,031.62$ \\
\hline \multicolumn{6}{|c|}{ DIVISION 3. GROUND WORK } \\
\hline 3.2. (1) & Landfill & $\mathrm{M}^{3}$ & 996.90 & $118,589.59$ & $118,221,957.54$ \\
\hline \multicolumn{5}{|c|}{$\begin{array}{c}\text { Total Price Work of DIVISION } 3 \text { (in Recapitulation of Estimated Price of } \\
\text { Work) }\end{array}$} & $118,221,957.54$ \\
\hline \multicolumn{6}{|c|}{ DIVISION 7. STRUCTURE } \\
\hline $7.1(8)$ & K-125 Concrete & $\mathrm{M}^{3}$ & 2208.30 & $1,075,151.78$ & $2,374,257,683.52$ \\
\hline $7.6(1)$ & $\begin{array}{l}\text { Erection of Ironwood } 10 \times 10-200 \\
\text { cm }\end{array}$ & $M^{1}$ & 73472.00 & 58600.35 & $4,305,484,915.20$ \\
\hline $7: 11(1)$ & Pipework 1 & "M & 6888.00 & 14630.74 & $100,776,546.30$ \\
\hline
\end{tabular}

Calculation Analysis of Working Time. The working time is made in the curve $\mathrm{S}$, the plan taken from the time calculation of the method of implementation of the work of analysis of Bina-marga Year 2010 Revised.

Implementation Period $=$ Volume $/$ Capacity Production per day 
Table 3 - Calculation Working Time of In situ Concrete

\begin{tabular}{|c|c|c|c|c|}
\hline No & Description & Weight & \multicolumn{2}{|c|}{ Implementation time } \\
\hline 1 & Mobilization & 0,042 & 14 & Days \\
\hline 2 & Digging For Drainage \& Water Channel & 1,321 & 187 & Days \\
\hline 3 & Landfill & 0,145 & 42 & Days \\
\hline 4 & K-250 Concrete & 70.225 & 722 & Days \\
\hline 5 & K-125 Concrete & 2.623 & 22 & Days \\
\hline 6 & Reinforcing Steel & 21.23 & 359 & Days \\
\hline 7 & Erection of Ironwood $10 \times 10-200 \mathrm{~cm}$ & 4.314 & 263 & Days \\
\hline 8 & Pipework 1 & $" .101$ & 50 & Days \\
\hline & Percentage & 100,000 & - & - \\
\hline & Estimated Time plan in accordance with S Curve & - & \multicolumn{2}{|c|}{2 Years 1 Month } \\
\hline
\end{tabular}

Table 4 - Supplies Precast Concrete Working Time

\begin{tabular}{|c|c|c|c|c|}
\hline No & Description & Weight & \multicolumn{2}{|c|}{ Timeimplementing } \\
\hline 1 & Mobilization & 0,062 & 14 & Days \\
\hline 2 & Cut For Drainage \& Water Channel & 2,149 & 204 & Days \\
\hline 3 & U-ditch $1 \times 1.5$ & 1,275 & 45 & Days \\
\hline 4 & U-ditch $1.5 \times 2$ & 0,443 & 12 & Days \\
\hline 5 & U-ditch $3 \times 2$ & 5,648 & 127 & Days \\
\hline 6 & U-ditch $4 \times 2$ & 32,315 & 569 & Days \\
\hline 7 & U-ditch $6 \times 2.5$ & 7,647 & 115 & Days \\
\hline 8 & U-ditch $7 \times 2.5$ & 40,131 & 481 & Days \\
\hline 9 & Landfill & 0,177 & 43 & Days \\
\hline 10 & K-125 Concrete & 3,555 & 20 & Days \\
\hline 11 & Erection of Ironwood $10 \times 10-200 \mathrm{~cm}$ & 6,447 & 263 & Days \\
\hline 12 & Pipework 1 & 0,151 & 50 & Days \\
\hline & Percentage & 100,000 & & \\
\hline & Estimated Time plan in accordance with S Curve & & \multicolumn{2}{|c|}{1 Year 8 Months } \\
\hline
\end{tabular}

Construction Quality Analysis. In general, from the survey results in the form of quality questionnaires with construction methods that occurs in the field for both precast concrete and In Situ concrete, the results of the questionnaire are divided into 4 parts namely pre construction, construction implementation, post construction, and construction quality based on the results of the field are as follows:

Pre-Construction. In Situ Concrete construction method: the executive prepares the K250 concrete jobmix; trial test as a reference of job implementation by using K-250 jobmix data; the precast concrete construction method: factory visit, conduct a random test of precast that will be used in the field, test can be performed with hammer test, core (for thickness) test, concrete tension test, and concrete bending test according to K-250.

Construction Implementation. In Situ Concrete construction method: Implementation of in situ concrete should pay attention that neatness of the installation of formwork must be in accordance with the plan design; the neatness of the reinforcement installation is good in both reinforcement size and reinforcement length; the distance of reinforcement towards the formwork remains to be observed to ensure that a concrete blanket is there; the cleanliness must always be maintained: not workable in a hazard situation even in small intensity; each foundry always provides the test specimen and test slump; conduct the hammer test on the finished channel at least 28 days with K-250 quality.

The precast concrete construction method: always check the U-ditch conditions that come in both basecamp and location and it should not be in a state of damage; conduct a random test of precast U-ditch that comes, the test can be performed by hammer test, core (for thickness), concrete tension test, and bending test of concrete with K-250 quality; not applicable if in a state of intense rainfall.

Post Construction. In Situ Concrete Cast construction method: re-check the straightness of the channel; ensure that all work is in accordance with the quality planned.

The precast concrete construction method: check that the U-ditch condition that is carried out should not be in a defective condition; ensure that all work is in accordance with the quality planned. 
Construction Quality based on Field Results. In the implementation, neatness and construction quality are seen, namely: the dimension size in the field is more assured and precise on precast concrete than In Situ Concrete; the quality of precast concrete is more assured because it is manufactured by the factory coupled with the quality of the concrete that has been determined from the In Situ Concrete.

\section{CONCLUSION AND SUGGESTIONS}

Some things can be concluded in this study, which are:

Costs required in the implementation of construction methods of Precast Concrete and In Situ Concrete are: RAB for In Situ Concrete construction method is Rp. 109,790,340,000.00; $\mathrm{RAB}$ for Precast Concrete construction method is Rp. 73,460,740,000.00.

Cost efficiency is about $33.09 \%$ (Rp. 36,329,625,506.00).

Time required in the implementation of Precast Concrete and In Situ Concrete methods on site are: In Situ Concrete Construction Method is for 2 years and 1 month; Precast Concrete Construction Method is for 1 Year 8 Months; Time Efficiency is about $20.00 \%$ (5 months).

In the implementation, the neatness and implementation quality can be seen as follows: the surface of precast concrete is smoother and tidier than In Situ Concrete; the dimension size of the field is more assured and precise on precast concrete than In Situ Concrete; the quality of precast concrete is more assured because it is manufactured by the factory coupled with the quality of the concrete that has been determined from the In Situ Concrete; questionnaire results toward 30 respondents, $70 \%$ opinion stated that precast concrete is more effective and efficient in the selection of implementation method than In Situ Concrete.

A review is needed in the effectiveness and efficiency of the implementation of the channel length that will be done. In designing the channel, it should be planned according to the standard size produced in the factory. If the location of work is not on the highway, then the creation of access roads following the cost of transportation and others must be considered. For work on the primary channel, the ideal design and the creation of condor channels during the execution of the work should also be considered. It needs to immediately make prevention efforts technically by drafting the master plan of channel / drainage in an integrated and non-technically by doing socialization to related institutions and society.

\section{REFERENCES}

1. Abduh, M. 2007, Technological Innovation and Precast Concrete Systems in Indonesia: A Value Chain Analysis. Seminar and Exhibition of IPR 2007.

2. Ervianto, W. I. (2005). Construction Project Management. Yogyakarta: Andi Publisher.

3. Ervianto, W. I. (2006). Technology Exploration in Precast Concrete Construction Project and beksiting. Yogyakarta: Andi Offset.

4. Gibb, A. G. F. (1999). Off-Site fabrication. John Wiley and Son. New York. USA in

5. Ibrahim, Y.H.M. (2003). Business Feasibility Study, Revised Edition. Jakarta: PT. Rineka Cipata.

6. Jarkas, A.M. (2005). An investigation into the influence of build ability factors on productivity of in situ reinforced concrete construction. An Investigation into the Influence of Build ability Factors on Productivity of in situ Reinforced Concrete Construction.

7. Kulkarni, S.A. (2008). Finite element analysis of precast hybrid-steel concrete connections under cyclic loading. Journal of constructional steel research, 64(2), 190201.

8. Kurama, Y.C. (2000). Unbonded post-tensioned precast concrete walls with supplemental viscous damping. ACI Structural Journal, 97(4), 648-658. 
9. Marriott, D., Pampanin, S., \& Palermo, A. (2009). Quasi-static and pseudo-dynamic testing of unbonded post-tensioned rocking bridge piers with external replaceable dissipaters. Earthquake engineering \& structural dynamics, 38(3), 331-354.

10. Mirmiran, A., Kulkarni, S., Castrodale, R., Miller, R., \& Hastak, M. (2001). Nonlinear continuity analysis of precast, prestressed concrete girders with cast-in-place decks and diaphragms. PCl Journal, 46(5).

11. Pampanin, S., Priestley, M. N., \& Sritharan, S. (2001). Analytical modelling of the seismic behaviour of precast concrete frames designed with ductile connections. Journal of Earthquake Engineering, 5(03), 329-367.

12. Soeharto, I. (1999). Project Management: From Conceptual to Operational, Volume 1. Jakarta: Erlangga.

13. Suhardjono. (1984). Urban Drainage. Malang: UPT Faculty of Engineering Brawijaya.

(C) 2017 by the authors. Licensee RJOAS, Orel, Russia. This article is an open access article distributed under the terms and conditions of the Creative Commons Attribution (CC BY) license: http://creativecommons.org/licenses/by/4.0/ 